DOI: 10.1515/afmnai-2017-0002

UDC: 614.253.5:316.47:159.97

Original article

\title{
Comparing Mental Illness Stigma among Nurses in Psychiatric and Non-Psychiatric Wards in Tabriz University of Medical Sciences
}

\author{
Hossein Ebrahimi ${ }^{1}$, Mohammad Asghari Jafarabadi², Hossein Namdar Areshtanab ${ }^{1}$, Maryam \\ Pourabbas ${ }^{4}$, Ahmad Dehghan ${ }^{5}$, Maryam Vahidi ${ }^{6}$ \\ ${ }^{1}$ Department of Psychiatric Nursing, Nursing and Midwifery Faculty, Tabriz University of Medical Sciences, Tabriz, \\ Iran \\ ${ }^{2}$ Road Traffic Injury Research Center, Tabriz University of Medical Sciences, Tabriz, Iran \\ ${ }^{3}$ MSc Student, Department of Psychiatric Nursing, Nursing and Midwifery Faculty, Tabriz University of Medical \\ Sciences, Tabriz, Iran \\ ${ }^{4}$ Nursing Practitioner in Psychiatric Ward, Tabriz University of Medical Science, Tabriz, Iran \\ ${ }^{5}$ PhD Student of Teaching Nursing, Tabriz University of Medical Science, Tabriz, Iran
}

\begin{abstract}
SUMMARY
Stigma can complicate people's mental health problems by affecting different sides of personal life, increasing negative attitudes, causing discriminatory behavior towards them, and reducing the chances of recovery and returning to normal life. This research aims to compare the stigma of mental illness among nurses working in psychiatric and non-psychiatric wards in Tabriz University of Medical Sciences. A total of 240 nurses participated in this descriptive and analytic study. The data were collected using a demographic questionnaire and the Community Attitudes towards the Mentally Ill (CAMI) Scale, which is a 40-item self-report questionnaire. All data were analyzed using SPSS 13 . The majority of nurses have a medium level of stigma toward people with mental illness, and there is no significant relation between the type of wards and mean stigma scores. After eliminating factors such as mental illness in nurses and their families, it seems that only working with people with mental illness in psychiatric wards is not enough to create a positive attitude toward them. Additionally, the less physical activity and taking advantage of legal benefits of work hardship for psychiatric nurses, low income, and stigma toward psychiatric nursing, probably may make a difference in inclining to work in psychiatry ward between the two groups in spite of relatively equal stigma scores.
\end{abstract}

Key words: stigma, nurses' attitude, psychiatric wards, contact

Corresponding author:

Hossein Namdar Areshtanab

E-mail: namdarh@tbzmed.ac.ir 


\section{INTRODUCTION}

Mental patients suffer from not only the mental illness but also its stigma (1). Stigma may be affixed to patients by other members of the society due to their perceived mental illness or physical disabilities (2). Stigma and discrimination can affect all aspects of an individual's life (3). High levels of stigma can complicate people's mental health problems, increasing negative attitudes, causing discriminatory behavior towards them, and reducing the chances of recovery and returning to normal life (4). Despite varied activities and movements' stigma, stigmatized attitudes still exist $(5,6)$. People with mental illness acquire stigma from different sources such as the community, family, workmates, and mental healthcare providers (7). Studies show that the frequency of stigma varies across nations and has increased in recent years $(8,9)$. People with mental illness are far more likely to be the victims of stigma than those with physical diseases (10). Stigma and discrimination in connection with the mentally ill is the biggest obstacle in improving effective care and treatment. The mortality rates among psychiatric patients with medical comorbidity is higher than among other patients (11). According to studies, the mentally ill are more strongly prone to lowerquality medical cares, and $40 \%$ of those seeking medical cares do not receive sufficient services (12).

One important and effective factor in the attitude toward mental illness is having a regular contact with it. According to studies, mentally ill people's families and those with mental health problems have positive attitudes toward mental illness $(13,14)$. In addition, the reduction of stigma-related attitude is observed among those who intend on their own to have interpersonal contact with mentally ill people (15). Creating the opportunity to be in contact with people with mental illness has been suggested in anti-stigma programs (16). Mental health nurses who work with mentally ill people continuously have an important position in forming attitudes towards the mentally ill. They also work as a model for communicating with people with mental illness (17). Inconsistent results have been achieved in various studies on stigma among health professionals. Although some studies stress that the interpersonal contact between health professionals and people with mental illness reduces stigma, results vary in other studies $(18,19)$. A study which compared the attitudes of mental health professionals and ordinary people showed that psychiatrists have more negative stereotypes than the general public, and that mental health professionals want to have a social distance from people with mental illness similar to the general public (20). Another study found that professionals tend to be less optimistic about prognosis and less positive about likely long-term outcomes when compared with the general public. Unqualified staff (orderlies) held more positive as well as more negative attitudes than qualified staff (registered nurses) (21). Quoting Weller and Grunes (1988), Callaghan (1997) argued that having continuous contact with these patients had a good impact on attitude toward them (22). Since nurses in psychiatric wards continually deal with mentally ill people and non-psychiatric nurses are less in contact with these patients, this research was conducted aiming to compare the stigma of mental illness among nurses working in psychiatry and non-psychiatry wards in Tabriz University of Medical Sciences.

\section{METHODS}

This is a descriptive analytic research study with statistical population of all nurses (holding Bachelor and Master's degrees) working in inpatient wards of Teaching Hospitals in Tabriz.

The research setting was inpatient wards of the hospitals of Tabriz University of Medical Sciences. A sample of those working only in the psychiatry center was selected by the census sampling method because of a limited number of psychiatric wards in Razi Hospital. Inclusion criteria were having nursing education (Bachelor or Master's degrees), caring for patients in the educational hospital for at least 6 months, not having work experience in psychiatric wards for nurses working in non-psychiatric wards, not having administrative positions in the ward and hospital, not having mental disorders, and not having a family member with mental illness. As it was impossible to directly ask nurses about their family's mental disorder and its effect on research results, all criteria were written in a separate piece of paper and the nurses were asked not to participate in case of not meeting any of the criteria, and there were no needs to refer to the type of limitation. A sample of those working in non-psychiatric wards was randomly selected from the nurses working for educational and medical centers. A list of all non-psychiatric nurses of all educational and medical centers was prepared, and the number of samples was found based on the 
ratio of the number of nurses of the centers to the total sample of that group. The sample volume for each group was considered 120 . The data were collected using a demographic questionnaire and the Community Attitudes Towards the Mentally Ill (CAMI) scale which consists of 40 items scored from on a 5-point Likert scale ranging from 1 (strongly disagree) to 5 (strongly agree). Total scores ranged from 40 to 200 .

The questionnaire comprises four factors: (1) authoritarianism - referring to a view of the mentally ill as inferior people who require coercive handling; (2) benevolence - corresponding to a paternalistic and sympathetic view of the mentally ill; (3) social restrictiveness (SR) - referring to a view that the mentally ill are a threat to the society and should be restricted; and (4) community mental health ideology - referring to the acceptance of mental health services and mentally ill patients in the community.

The questionnaire was validated by a translation-retranslation procedure. The main context was first translated into Persian by two skillful translators. The two translated texts were then compared and examined in terms of quality. Finally, primary sentences were integrated and combined to choose the most suitable translation for phrases and reach an agreement on a common Persian version in order to convert the questionnaire into a single translated version. The final translated version was submitted to two other translators who had not seen the English version to be more assured of the reliability. After comparing the versions translated into English with the original version, the general quality of the translation was studied. Afterwards, 10 faculty members in Tabriz University of Medical Sciences studied the translation in order to validate it by content. The reliability coefficient was estimated to be 0.68 to 0.88 , showing that the questionnaire is reliable. The questionnaire reliability was studied again and estimated by a preliminary study on 30 individuals to be 0.77 by Cronbach's alpha. All data were analyzed using SPSS 13.

Quantitative variables (mean) and qualitative variables (frequency) were reported at the confidence level of $95 \%$. In a single-variant analysis, t-tests were used to compare stigma areas and the total scores for nurse groups, and covariance analysis was employed to adjust the effect of potentially confounding variables including age, education, work turn, length of contact with mentally ill people, experiencing violence from the patients, etc. In the multivariate analysis, Hoteling T2 and MANCOVA were adopted to adjust the effect of confounding variables. The significance level was considered to be 0.05 ( $p<0.05)$.

This study was approved by the Ethics Committee of Tabriz University of Medical Sciences in 2014.

\section{RESULTS}

Questionnaires were not received from 240 distributed questionnaires. Twenty were eliminated from the 221 questionnaires because they were incomplete and due to probable bias. Finally, 93 questionnaires related to psychiatric nurses and 105 for those in non-psychiatric wards were analyzed. The majority of participants were married women, holding Bachelor's degrees, and employed by contract.

Based on the findings, mean \pm SD age and work experience of both groups were $32.48 \pm 5.98$ and $8.12 \pm$ 5.59. The work experience for the group working in nonpsychiatric ward was 0.00 , and it was 6.29 for the other group, with a standard deviation of 4.30. Eighty-six point seven percent of non-psychiatric nurses were reluctant to work in psychiatric wards in the future, and $63.3 \%$ of psychiatric nurses liked to continue their work as before. Tables 1 and 2 summarize the personal and social characteristics of both groups in detail.

Mean \pm SD stigma for all participants was $103.15 \pm$ 12.00. Table 3 presents the total stigma score and its subscales for both groups, and compares the two groups. Data analysis showed that no significant statistical difference was observed for the stigma score between the two groups.

Studying the relation between personal, social, and occupational characteristics and stigma indicated that stigma was not associated with variables of age, work experience, experience of working in the psychiatric ward, number of beds, wage and salary, academic degree, violence from the mentally ill, job status, tendency to continue work in the psychiatric ward in the future, and emphasis on working in nonpsychiatric wards. However, variables of sex, marriage, and tendency to working in the psychiatric ward were found to be significantly linked with benevolence, and the variable of the number of work shifts was also significantly associated with social restrictiveness, community mental health ideology, and total stigma (Table 3). 
Table 1. Comparison of demographic characteristics of two groups of nurses working in psychiatric and non-psychiatric wards

\begin{tabular}{|c|c|c|c|c|c|}
\hline $\begin{array}{l}\text { Demographic } \\
\text { characteristics }\end{array}$ & $\begin{array}{c}\text { Non- } \\
\text { psychiatr } \\
\text { ic ward } \\
\end{array}$ & $\begin{array}{l}\text { Psychiat- } \\
\text { ric ward }\end{array}$ & $\begin{array}{l}\text { Demographic } \\
\text { characteristics }\end{array}$ & $\begin{array}{c}\text { Non- } \\
\text { psychiatric } \\
\text { ward }\end{array}$ & $\begin{array}{l}\text { Psychiatric } \\
\text { ward }\end{array}$ \\
\hline Sex: & & & $\begin{array}{l}\text { Violence from mentally ill } \\
\text { patient: }\end{array}$ & & \\
\hline $\begin{array}{l}\text { Male } \\
\text { Female }\end{array}$ & $\begin{array}{l}12 \\
93\end{array}$ & $\begin{array}{l}38 \\
55\end{array}$ & $\begin{array}{l}\text { Yes } \\
\text { No }\end{array}$ & $\begin{array}{l}21 \\
84\end{array}$ & $\begin{array}{l}77 \\
16\end{array}$ \\
\hline $\begin{array}{l}\text { Marital status: } \\
\text { Married } \\
\text { Single } \\
\text { Divorced } \\
\text { Widow }\end{array}$ & $\begin{array}{c}69 \\
35 \\
0 \\
1\end{array}$ & $\begin{array}{c}76 \\
16 \\
1 \\
0\end{array}$ & $\begin{array}{c}\text { Like to work in psychiatric } \\
\text { ward in future: } \\
\text { Yes } \\
\text { No }\end{array}$ & $\begin{array}{l}14 \\
92\end{array}$ & $\begin{array}{l}- \\
-\end{array}$ \\
\hline $\begin{array}{l}\text { Education degree: } \\
\text { BA } \\
\text { MA } \\
\text { PhD }\end{array}$ & $\begin{array}{c}97 \\
9 \\
0\end{array}$ & $\begin{array}{c}85 \\
7 \\
1\end{array}$ & $\begin{array}{l}\text { Emphasis on working in non- } \\
\text { psychiatric ward when hiring } \\
\qquad \begin{array}{c}\text { Yes } \\
\text { No }\end{array}\end{array}$ & $\begin{array}{l}65 \\
40\end{array}$ & $\begin{array}{l}- \\
-\end{array}$ \\
\hline $\begin{array}{l}\text { Employment } \\
\text { status: } \\
\text { Formal } \\
\text { Contract } \\
\text { Agreement } \\
\text { Plan }\end{array}$ & $\begin{array}{l}11 \\
56 \\
18 \\
20\end{array}$ & $\begin{array}{c}16 \\
74 \\
1 \\
2\end{array}$ & $\begin{array}{c}\text { Salary and wage: } \\
\text { Low } \\
\text { Average } \\
\text { Good } \\
\text { Excellent }\end{array}$ & $\begin{array}{c}31 \\
63 \\
10 \\
1\end{array}$ & $\begin{array}{c}38 \\
45 \\
7 \\
0\end{array}$ \\
\hline $\begin{array}{l}\text { Shift schedule: } \\
\text { morning fixed } \\
\text { evening fixed } \\
\text { fixed nights } \\
\text { changing }\end{array}$ & $\begin{array}{c}4 \\
2 \\
2 \\
97\end{array}$ & $\begin{array}{c}24 \\
0 \\
0 \\
69\end{array}$ & $\begin{array}{c}\text { Number of shifts in each month: } \\
\text { Fewer than } 30 \\
30-35 \\
35-40 \\
\text { More than } 40\end{array}$ & $\begin{array}{c}33 \\
54 \\
10 \\
9\end{array}$ & $\begin{array}{c}38 \\
25 \\
22 \\
6\end{array}$ \\
\hline $\begin{array}{l}\text { Working in a } \\
\text { psychiatric ward } \\
\text { with their desire: } \\
\text { Yes } \\
\text { No }\end{array}$ & $\begin{array}{l}- \\
-\end{array}$ & $\begin{array}{l}53 \\
40\end{array}$ & $\begin{array}{l}\text { Willing to continue working } \\
\text { in psychiatric ward: } \\
\qquad \begin{array}{c}\text { Yes } \\
\text { No }\end{array}\end{array}$ & $\begin{array}{l}- \\
-\end{array}$ & $\begin{array}{l}59 \\
34\end{array}$ \\
\hline
\end{tabular}


Table 2. Comparison between mean and standard deviation of other demographic characteristics of nurses working in psychiatry and non-psychiatry wards

\begin{tabular}{c|c|c|c}
\hline \hline Ward & Age & Experience & $\begin{array}{c}\text { Experience in } \\
\text { psychiatry ward }\end{array}$ \\
\hline $\begin{array}{c}\text { Psychiatry } \\
\text { Non-psychiatry }\end{array}$ & $35.10(5.37)$ & $9.98(5.86)$ & $6.18(4.31)$ \\
\hline \hline
\end{tabular}

Table 3. Comparison between mean stigma and its subscales among nurses working in psychiatry and nonpsychiatry wards

\begin{tabular}{c|c|c|c}
\hline \hline $\begin{array}{c}\text { Stigma and } \\
\text { its subscales }\end{array}$ & Ward & $\begin{array}{c}\text { Mean (standard } \\
\text { deviation) }\end{array}$ & Statistical indexes \\
\hline \multirow{2}{*}{ Authoritarian } & Psychiatric & $26.04(3.32)$ & $\mathrm{t}(-0.459)$ \\
\cline { 2 - 4 } & Non-psychiatric & $26.26(3.63)$ & $\mathrm{p}(0.64)$ \\
\hline \multirow{2}{*}{ Benevolence } & Psychiatric & $24.78(3.90)$ & $\mathrm{t}(-0.188)$ \\
\cline { 2 - 4 } & Non-psychiatric & $26.35(2.61)$ & $\mathrm{p}(0.85)$ \\
\hline \multirow{2}{*}{\begin{tabular}{c} 
Social restrictiveness \\
\cline { 2 - 4 }
\end{tabular}} & Psychiatric & $25.88(4.75)$ & $\mathrm{p}(0.27)$ \\
\cline { 2 - 4 } Community mental & Non-psychiatric & $26.52(3.61)$ & $\mathrm{t}(0.189)$ \\
\cline { 2 - 4 } health ideology & Psychiatric & $26.01(4.61)$ & $\mathrm{p}(0.85)$ \\
\hline \multirow{2}{*}{ Total score } & Non-psychiatric & $25.90(4.09)$ & $\mathrm{t}(-0.473)$ \\
\cline { 2 - 4 } & Psychiatric & $102.75(13.02)$ & $\mathrm{p}(0.63)$ \\
\cline { 2 - 4 }
\end{tabular}

\section{DISCUSSION}

This research aimed to compare the stigma of mental illness among nurses working in psychiatric and non-psychiatric wards in Tabriz University of Medical Sciences. According to the findings, the two groups did not significantly differ from each other on mental illness stigma. The stigma scores among psychiatric and nonpsychiatric nurses were 102.75 (13.02) and 103.55, respectively. Research results are consistent with those of a collection of studies (22, 24-26). Callaghan compared the attitudes of two groups of nursing students differentiated based on having taken a psychiatric secondment. He concluded that there was no difference in attitudes to mental illness between the group who had taken a psychiatric secondment and the group who had not (22).

Having studied nursing stigma in five European countries, Chambers found that nurses had generally positive attitudes towards mental illness. According to him, about one fifth of nurses in senior positions and their attitude were more positive. It may be due to the difference in the amount and type of contact with patients. Finally, he concluded that no significant association existed between attitude toward mental illness and contact (25).

Results of the present study are inconsistent with those of some other studies which concluded that the experience of being in contact with mentally ill people was associated with positive attitudes. In a study on nursing students, Surgenor concluded that nursing students in their final year of training reported a significantly more positive attitude than those in their first year of training (27-29). The reason was probably the difference between the type and amount of contact. In Surgenor's research, there was a sample of students with mere exposure to psychiatric settings and mental illness for five weeks in a psychiatric ward in the third year who did not have any responsibility toward the patients. Students might have worked only on morning 
shifts and might not have seen more violent and uneasy patients on the evening and night shifts (30). In the present study, participants were in contact with patients only in the work setting. Lack of mental disease in them and their families was one of the inclusion criteria. In Surgenor's research, however, $83 \%$ of students had previous contact with someone with mental disorder and a more positive attitude was reported toward them. It is not sufficient to be in contact with patients to foster positive attitudes toward them (31). Direct contact with those who have experienced a successful treatment is more effective (29). Since nurses are mostly confronted with patients at an acute stage of their illness, they have more negative emotional and behavioral reaction towards them (13).

Some studies report negative attitudes among psychiatric nurses and community mental health. Li et al. (2014) concluded that there was a high stigma level, negative attitude, and reluctance to be in relation with patients among the community of mental health staff (32). Ahmead (2010) studied psychiatric nurses' attitudes in Palestine and reported negative attitudes among psychiatric nurses having direct contact with patients (31).

Our research on psychiatric wards was in some respects similar to the Ahmead's study. In both cases, most patients were hospitalized for years because of being rejected by their families. Sufficient rehabilitation centers do not exist for treating and caring for these patients. Therefore, the nurses are responsible for their treatment, feeding, hygiene, and safety in inpatient settings. Long-term contact with these patients affects the attitude of nurses, and it is difficult to have optimistic feelings especially when the patients suffer from chronic mental diseases (22). Mårtenson (2014) concluded that nurses who worked with patients who made an improvement and returned to normal life were likely to have more positive attitudes compared to those who worked with patients with long-term and recurrent mental illnesses (29).

Studying various research results shows that working in a psychiatric ward and having contact with mentally ill people are not the only reasons for positive attitude toward patients. A number of studies reported that work experience and type of ward were not associated with staff and students' attitude $(24,27,33)$. In fact, contact in other forms such as being mentally ill or having a family member or a friend with mental illness contributes more to the creation of positive attitudes. Mårtenson found that nurses who currently or previously had a close friend with mental illness had more positive attitudes than others (29).

According to the CAMI criteria, the two groups did not significantly differ from each other on the stigma mean score. However, $86.7 \%$ of nurses working in nonpsychiatric wards did not like to work in the psychiatric ward in the future, and $63.3 \%$ of nurses working in the psychiatric ward liked to continue to work there. In his research, Surgenor concluded that psychiatric nursing was the least popular future choice of students and, as a group, they held diverse views and attitudes about psychiatric illness and psychiatric nursing similar to the general public (27).

Statistically, there was no significant correlation between this variable and stigma. Factors such as fewer physical tasks compared with non-psychiatric wards, more annual work leaves, and early retiring based on work hardship law are the reasons for psychiatric nurses to like to continue their work as before. In contrast, less salary and concern about new and unknown work experiences are probable reasons for the reluctance of non-psychiatric nurses to work in the psychiatric ward. A better explanation for such reluctance despite the average stigma is the cultural context. Although these nurses do not have negative attitudes toward mental illness, working in psychiatric hospitals is not highly valued in their cultural context, and mental health staff is also subjected to a form of 'stigma by association'. This stigma may have more sinister consequences for mental health staff and students (34).

The statistical population included nurses did not arbitrarily choose the hospital working for. The level of their authority is such that in case they do not like to work in a particular hospital, they can change their position with another nurse if possible. Point three six percent of participants working in non-psychiatric wards were stressed to work in wards other than the psychiatric ward at the time of being hired. Such a difference may reveal the effect of relation with mentally ill people and working in the psychiatric ward on attitudes toward mental illness. As such, psychiatric nurses will gradually have a positive view of working in the psychiatric ward. However, other nurses cannot have such close and continuous contact with mentally ill people. Thus, they have more negative attitudes and do not like to work in psychiatric wards in the future.

The issue of tendency to work in psychiatric wards was investigated in none of the studies examining health professionals' attitude towards the mentally ill. If the reason of the issue is the negative attitude, those who have accepted to work for a psychiatric hospital may 
have had more positive views $(27,34)$. If this is true, findings obtained by questionnaires contradict true outlooks. Studying stigma and attitude toward mentally ill patients only by self-report questionnaires does not seem ideal.

These tools and researcher-developed checklists are then suggested to be both employed in future studies. The type of mental disease is recommended to be specified for the sample. In studies investigating the tendency to work in psychiatric wards, the reason for the tendency or reluctance should also be asked. The effect of different types of contacts including caring at the hospital, or having a family member, a friend, a neighbor, etc. with mental illness on attitudes toward patients should be separately measured.

\section{CONCLUSIONS}

Only having contact with the mentally ill in a psychiatric ward as simply working with them is not enough for creating positive attitudes, and the quality and quantity of contacts is more effective on changing the stigma.

\section{Acknowledgments}

The authors would like to thank all the nurses for their participation in the study. We thank the ViceChancellor of Research at Tabriz University of Medical Sciences for the financial support of the study.

\section{References}

1. Link BG, Phelan JC. Conceptualizing Stigma. Annual Review of Sociology2001; 27: 363-85. https://doi.org/10.1146/annurev.soc.27.1.363

2. Younesi SJ. Stigma and infertility in Iran-coping skills. JRI 2002;. 3: 74-6(In persain).

3. Byrne P. Stigma of mental illness and ways of diminishing it. Advances in Psychiatric Treatment 2000; 6: 65-72. https://doi.org/10.1192/apt.6.1.65

4. Sartorius N. Stigma and mental health. The Lancet 2007; 370: 810-1. https://doi.org/10.1016/S0140-6736(07)61245-8

5. Crisp A. Changing minds: every family in the land-an update on the College's campaign. Schizophr Bull 2000; 24: 267-8.

\section{https://doi.org/10.1192/pb.24.7.267}

6. Crisp A, Gelder M, Goddard Eet al. Stigmatization of people with mental illnesses: a follow-up study within the Changing Minds campaign of the Royal College of Psychiatrists. World Psychiatry 2005;4: 106-13.

7. Wahl OF. Mental health consumers' experience of stigma. Schizophr Bull 1999;25: 467. https://doi.org/10.1093/oxfordjournals.schbul.a03 $\underline{3394}$

8. Angermeyer $\mathrm{MC}$ and Matschinger H. Social distance towards the mentally ill:Results of representative surveys in the Federal Republic of Germany.Psychol Med 1997; 27: 131-41. 
9. Phelan JC, Link BG, Stueve A and Pescosolido BA. Public conceptions of mental illness in 1950 and 1996: What is mental illness and is it to be feared? J Health SocBehav 2000;41: 188-207. https://doi.org/10.2307/2676305

10. Socall DW,Holtgraves T.Attitudestoward the mentally ill: The effects of label and beliefs. Sociol Q 1992;33: 435-45.

https://doi.org/10.1111/j.1533-8525.1992.tb00383.x

11. Kongable GL,Tarko M. Psychosocial aspects of medically compromised persons. In: Psychiatric Nursing for Canadian Practice.Austin W, Boyd MA (eds). Lippincott Williams \&Wilkins,Philadelphia press, 2006.

12. Landino R. Buckley JM. Stigma of Mental Illness Continues to Impede Early Diagnosis and Treatment of Affective Illness in the United States. 2009.

13. Ebrahimi H, Namdar H, Vahidi M. Mental illness stigma among nurses in psychiatric wards of teaching hospitals in the north-west of Iran. Iran J Nurs Midwifery Res 2012; 17:534-8.

14. Lauber C, Anthony M, Ajdacic-Gross Vet al..What about psychiatrists' attitudes to mentally ill people? Eur Psychiatry 2004; 19: 423-7.

15. Song LY, Chang LY, Shih CYet al. Community attitudes towards the mentally ill: the results of a national survey of the Taiwanese population. Int J Soc Psychiatry 2005;51:162-76. https://doi.org/10.1177/0020764005056765

16. Llerena A, Cáceres MC, Pe-as-LLedó EM. Schizophrenia stigma among medical and nursing undergraduates. Eu Psychiatry 2002; 17: 298-9.

https://doi.org/10.1016/S0924-9338(02)00672-7

17. Bjo rkman $\mathrm{T}$, Angelman $\mathrm{T}$, and Jonsson $\mathrm{M}$. Attitudes towards people with mental illness: a cross-sectional study among nursing staff in psychiatric and somatic care. Scand J Caring Sci 2008; 22: 170-7.

https://doi.org/10.1111/j.1471-6712.2007.00509.x

18. Angermeyer MC and Dietrich S. Public beliefs about and attitudes towards people with mental illness: a review of population studies. ActaPsychiatriaScandinavica 2006; 113: 163-79. https://doi.org/10.1111/j.1600-0447.2005.00699.x

19. Addison S.J. Thorpe S.J., Factors involved in the formation of attitudes towards those who are mentally ill. Soc Psychiatry PsychiatrEpidemiol 2004; 39: 228-34. https://doi.org/10.1007/s00127-004-0723-y

20. Nordt, C, Rössler W, LauberC. Attitudes of mental health professionals toward people with schizophrenia and major depression. Schizophrenia bulletin 2006; 32: 709-14.

https://doi.org/10.1093/schbul/sbj065

21. Foster K, Usher K, Baker JA, Gadai S, Ali S.Mental health workers' attitudes towards mental illness in Fiji. Aust JAdvNurs 2008; 25: 72-9.

22. Callaghan P, Shan CS, Yu LSet al. Attitudes towards mental illness: testing the contact hypothesis among Chinese student nurses in Hong Kong. J AdvNurs 1997;26:33-40. https://doi.org/10.1046/j.1365-2648.1997.1997026033.x

23. Taylor SM, Dear MJ.Saling community attitudes toward the mentally ill. Schizophrenia Bulletin 1981; 7: 225-40.

https://doi.org/10.1093/schbul/7.2.225

24. Hugo M. Mental health professionals' attitudes towards people who have experienced a mental health disorder. J PSYCHIATR MENT HLT 2001; 8: 419-25.

https://doi.org/10.1046/j.1351-0126.2001.00430.x 
25. Chambers M, Guise V, Välimäki M et al., Nurses attitudes to mental illness: a comparison of a sample of nurses from five European countries. Int J Nurs Stud 2010; 47: 350-62.

https://doi.org/10.1016/j.ijnurstu.2009.08.008

26. Barczyk AN. Relationship Between the Public's Belief in Recovery, Level of Mental Illness Stigma, and Previous Contact. Community Ment Health J.2015;51:38-47. https://doi.org/10.1007/s10597-014-9766-z

27. Surgenor LJ, Dunn J, Horn J.Nursing student attitudes to psychiatric nursing and psychiatric disorders in New Zealand. Int J Ment Health Nurs 2005;14:103-8. https://doi.org/10.1111/j.1440-0979.2005.00366.x

28. West K, Hewstone $M$, Lolliot S. Intergroup contact and prejudice against people with schizophrenia. J Soc Psychol 2014;154:217-32. https://doi.org/10.1080/00224545.2014.888327

29. Mårtensson G, Jacobsson JW, Engström M. Mental health nursing staff's attitudes towards mental illness: an analysis of related factors. J PsychiatrMent Health Nurs. 2014;21:782-8. https://doi.org/10.1111/jpm.12145
30. Vahidi M. Hosseinzadeh M. Investigation of Seclusion in one of the Psychiatric Wards in Razi Teaching Hospital of Tabriz. J Caring Sci2014; 3:297-300

31. Ahmead MK, Rahhal AA, Baker JA. Baker, The attitudes of mental health professionals towards patients with mental illness in an inpatient setting in Palestine. Int $\mathrm{J}$ Ment Health Nurs.2010;19:356-62. https://doi.org/10.1111/j.1447-0349.2010.00674.x

32. Li J, Li J, Thornicroft G, Huang Y. Levels of stigma among community mental health staff in Guangzhou, China. BMC psychiatry 2014; 14: 231.

https://doi.org/10.1186/s12888-014-0231-x

33. Minas H, Zamzam R, Midin Met al. Attitudes of Malaysian general hospital staff towards patients with mental illness and diabetes. BMC public health 2011; 11: 317. https://doi.org/10.1186/1471-2458-11-317

34. Thornicroft G, RoseD, Mehta N. Discrimination against people with mental illness: what can psychiatrists do? Advances in psychiatric treatment, 2010; 16: 53-9.

https://doi.org/10.1192/apt.bp.107.004481 


\title{
Poređenje stigmatizacije mentalnih oboljenja od strane medicnskih sestara na psihijatrijskim i nepsihijatrijskim odeljenjima Univerziteta medicinskih nauka u Tabrizu
}

\author{
Hossein Ebrahimi ${ }^{1}$, Mohammad Asghari Jafarabadi², Hossein Namdar Areshtanab, Maryam \\ Pourabbas ${ }^{4}$, Ahmad Dehghan 5 , Maryam Vahidi ${ }^{6}$ \\ ${ }^{1}$ Departman za sestrinstvo u psihijatriji, Fakultet za sestrinstvo i akušerstvo, Univerzitet medicinskih \\ nauka u Tabrizu, Tabriz, Iran \\ ${ }^{2}$ Centar za istraživanje povreda u saobraćaju, Univerzitet medicinskih nauka u Tabrizu, Tabriz, Iran \\ ${ }^{3}$ Student master studija, Departman za sestrinstvo u psihijatriji, Fakultet za sestrinstvo i obstetriku, \\ Univerzitet medicinskih nauka u Tabrizu, Tabriz, Iran \\ ${ }^{4}$ Kvalifikovana medicinska sestra na Psihijatrijskom odeljenju, Univerzitet medicinskih nauka u Tabrizu, \\ Tabriz, Iran \\ ${ }^{5}$ Student doktorskih studija na Sestrinstvu, Univerzitet medicinskih nauka u Tabrizu, Tabriz, Iran
}

\section{SAŽETAK}

Stigma može da iskomplikuje probleme mentalnog zdravlja ljudi tako što utiče na njihov lični život, pojačava negativne stavove i na taj način dovodi do diskriminacije takvih osoba, smanjujući mogućnosti za oporavak i povratak normalnom životu. Cilj ovog istraživanja bio je poređenje stigmatizacije mentalnih oboljenja od strane medicinskih sestara koje rade na psihijatrijskim i nepsihijatrijskim odeljenjima Univerziteta medicinskih nauka u Tabrizu. U ovoj deskriptivnoj i analitičkoj studiji učestvovalo je 240 medicinskih sestara. Podaci su prikupljeni primenom demografskog upitnika i CAMI skale koja predstavlja upitnik od 40 pitanja. Podaci su analizirani primenom SPSS13 softvera. Kod najvećeg broja medicinskih sestara prisutan je srednji nivo stigmatizacije mentalno obolelih i nije zabeležena značajna relacija između tipa odeljenja na kome rade i srednjih vrednosti stigmatizacije. Nakon eliminacije faktora poput mentalnih bolesti kod medicinskih sestara $i$ članova njihovih porodica, čini se da sam rad sa mentalno obolelim na psihijatrijskim odeljenjima nije dovoljan kako bi se formirao pozitivan stav prema ovoj populaciji. Pored toga, slaba fizička aktivnost i korišćenje zakonskih benefita zbog teškoća na radu, mala plata i stigmatizacija posla ovih medicinskih sestara verovatno dovode do razlike u biranju posla na psihijatrijskom odeljenju između ove dve grupe sestara, uprkos relativno jednakim skorovima stigmatizacije.

Ključne reči: stigma, stav medicinskih sestara, psihijatrijsko odeljenje, kontakt 